\title{
The importance of social interaction activities in the teaching-learning process of English as a Foreign Language
}

\author{
A importância de atividades de interação social no processo \\ ensino-aprendizagem de inglês como língua estrangeira
}

\author{
Laryssa Paulino de Queiroz Sousa* \\ Carla Janaina Figueredo**
}

\begin{abstract}
This research was conducted in a state school of Goiânia, in Goiás, Brazil, with fifteen students of a third-year group of high school, in 2014. The main ideas that led this study revolve around the importance of interaction in the English language teaching-learning process, the presence of the other and students' autonomy/selfregulation. The theoretical basis of this research derives from Bakhtinian dialogism (BAKHTIN, 1993, 2003; BARROS, 1997; BRAIT, 2005), Vygotskian sociointeractionism (VYGOTSKY, 1978; MOLL, 1990; LANTOLF; APPEL, 1994; REGO, 1995) and Freirean thoughts (FREIRE, 1996, 2005) about positioning students as agents of their own learning. The general objectives were: to verify the learners-participants' perceptions regarding the teaching-learning process of English, before and after the interventions; to observe how different forms of social interaction (T-S, T-Ss, S-T, S-S, Ss-Ss, Ss-T) ${ }^{1}$ can interfere in English classes of a third-year group from a state school; and to describe how the teacher-researcher perceives the experience of teaching English with its focus on social interaction. The methodology used is qualitative action research (THIOLLENT, 1986; ENGEL, 2000; MELLO; REES, 2011) and the instruments used to generate the data were questionnaires, field notes and interviews. The outcomes show that the learners could conceive English as a language possible to be appropriated by them, used to communicate, and they could also recognize the importance of the other in the teachinglearning process. Besides that, the teacher-researcher could perceive that interactive and effective classes were possible in that public school.
\end{abstract}

KEYWORDS: English language teaching-learning. Interaction. Dialogism. Autonomy.

RESUMO: Este estudo foi realizado em uma escola estadual de Goiânia, em Goiás, Brasil, com quinze alunos de um grupo de terceiro ano do ensino médio, em 2014. As principais ideias que conduziram este estudo giram em torno da importância da interação no processo de ensino-aprendizagem de língua inglesa, a presença do outro e autonomia/autorregulação dos alunos. A base teórica da pesquisa provém do dialogismo bakhtiniano (BAKHTIN, 1993, 2003; BARROS, 1997; BRAIT, 2005), do sociointeracionismo vigotskiano (VYGOTSKY, 1978; MOLL, 1990; LANTOLF; APPEL,

* Master's student from Programa de Pós-Graduação em Letras e Linguística, at the Federal University of Goiás. Email: laryssa.paulino1@gmail.com

** $\mathrm{PhD}$ in linguistics by the Federal University of Goiás. Associate university professor at Departamento de Línguas e Literaturas Estrangeiras of Faculdade de Letras, at the same university. Email: cjfigueredo2@gmail.com

${ }_{1}^{1} \mathrm{~T}$ - teacher; $\mathrm{S}$ - student; Ss - students 
1994; REGO, 1995) e dos pensamentos freireanos (FREIRE, 1996, 2005) que dizem respeito ao posicionamento dos estudantes como agentes de sua própria aprendizagem. Os objetivos gerais foram: averiguar as percepções dos aprendizes-participantes em relação ao processo de ensino-aprendizagem de inglês, antes e depois das intervenções; observar como diferentes formas de interação social ( $P-A, P-A s, A-P, A-A, A s-A s, A s-P)^{2}$ podem interferir em aulas de inglês de um grupo do terceiro ano de uma escola estadual; e descrever como a professora-pesquisadora percebe a experiência de ensinar inglês com seu foco voltado para a interação social. A metodologia usada é a pesquisa-ação qualitativa (THIOLLENT, 1986; ENGEL, 2000; MELLO; REES, 2011) e os instrumentos utilizados para gerar os dados foram questionários, notas de campo e entrevistas. Os resultados mostram que os alunos puderam perceber o inglês como língua possível de ser apropriada por eles, usada para comunicar, e também puderam reconhecer a importância do outro no processo de ensino-aprendizagem. Ademais, a professorapesquisadora pôde perceber que aulas interativas e efetivas foram possíveis naquela escola pública.

PALAVRAS-CHAVE: Ensino-aprendizagem de língua inglesa. Interação. Dialogismo. Autonomia.

\section{Introduction}

The lack of social interaction in the English teaching-learning process is a common aspect that can be observed in state schools. Thus, this research is justified by the need to develop interaction in the classroom, for as classes that are dull, monotonous and boring do not appeal to students, they consequently do not work effectively. Accordingly, Barcelos (2006, p. 155, 157) affirms that "the learning experience in public schools is characterized as bad and demotivating; [...] [which] suggests a vision of public schools as a site where students' expectancies towards the teaching of English are not fulfilled."3 Therefore, this study was proposed in order to try to alter such reality of a specific language classroom of a single public school, trying to verify, mainly, if through interventions the students would have a better acceptance towards English classes.

In order to develop this study, the theoretical background used was based on Bakhtinian dialogism (BAKHTIN, 1993, 2003; BARROS, 1997; BRAIT, 2005), Vygotskian sociointeracionism (VYGOTSKY, 1978; MOLL, 1990; LANTOLF; APPEL, 1994; REGO, 1995) and Freirean thoughts (FREIRE, 1996, 2005) about

\footnotetext{
$2 \mathrm{P}$ - professora; A - aluno(a); As - alunos(as)

${ }^{3}$ All the citations originally read in Portuguese were translated into English by us.
} 
positioning students as agents of their own learning. The methodology chosen was the qualitative action research (THIOLLENT, 1986; ENGEL, 2000; MELLO; REES, 2011) and the data were generated through an initial questionnaire, answered by twelve students, field notes made by the teacher-researcher, and interviews done with six learners (only three of them also answered the questionnaires), after all interventions ${ }^{4}$.

As its general objective, this study focuses on the impacts caused by social interaction activities in the teaching-learning process of English as a foreign language in a public school. Thereby, based on theoretical assumptions and on the participants' statements and experiences, this study sought to answer the following questions:

a) Which are the learners-participants' perceptions regarding the teachinglearning process of English, before and after the interventions?

b) How can different forms of social interaction (T-S, T-Ss, S-T, S-S, SsSs, Ss-T) interfere in English classes of a third-year group from a state school?

c) How does the teacher-researcher perceive the experience of teaching English with its focus on social interaction?

The paper is divided into four parts. In the introduction, we present what the study is about, mention its objectives and how it is organized. Next, we focus on interaction from Bakhtinian, Vygotskian and Freirean perspectives, respectively, linking them to some other topics. Then, in the methodology, we expose and explain how the data generation was carried out, the kind of approach chosen - qualitative action research -, the context, participants and the research procedures. After that, we address the data analysis. Finally, we show the results, answer the research questions and exhibit our final considerations.

\footnotetext{
${ }^{4}$ We justify our choice of the learners-participants who were interviewed, whose discourses are analyzed and discussed in the data analysis, in the section The study.
} 


\section{Focusing on interaction from Bakhtinian, Vygotskian and Freirean perspectives}

Firstly, we present some Bakhtinian main ideas regarding language, dialogism and alterity (BAKHTIN, 1993, 2003; BARROS, 1997; BRAIT, 2005). Next, from a Vygotskian perspective (VYGOTSKY, 1978; MOLL, 1990; LANTOLF; APPEL, 1994; REGO, 1995), we address how social interactions play an important role in people's teaching-learning process as well as their socio-cognitive development. Besides that, we explain the concept of zone of proximal development (ZDP) in order to support the previous ideas presented. Then, we discuss the concept of learner autonomy, from a Freirean perspective (FREIRE, 1996, 2005). Finally, we construct a dialogue between Bakhtin, Vygotsky and Freire, linking their theoretical assumptions previously addressed.

\section{Language, dialogism and alterity}

According to Bakhtin (1993, 2003), through the Word, one understands the world around them, for it is the key in social life; it is the connection between $I$ and you, between the self and the other. The author understands language as an entity formed by human beings and within them. Bernard-Donals (2001) mentions the transformation of the world through the Word, which produces discourses and is produced by them. When one verbalizes something, one appropriates words, they become their owners, but at the same time, the same words also belong to others. Discourses are polyphonic, generated by many voices that intersect and intertwine in space and time, flowing into the individual, becoming part of their voice.

Bakhtin claims that all verbalized discourses are the result of other discourses, which were once produced. The self as a being in the world only exists in a dialogic relation with the other. Thus, Barros (1997) asserts that this dialogic process is not only composed of the present moment, but also of the past and all cultural, social and historical aspects that lie in both times. The author explains that each individual is situated in a specific time, place and surrounded by social subjects who influence them. Regarding the past, Barros (1997) claims 
that an individual's ideas and discourses are originated from ideas and discourses once prior produced, so there is a connection between everything that was once created to everything that has been created.

Yaguello (1997, p. 16), referring to language as the main mediator of human relations, emphasizes that "sign and social situation are intrinsically linked," for signals are ideological and it is through them, through the word, through language, that social interactions occur. Thereby, dialogism is understood as the meaning connection established between two or more utterances. That is to say, when discursive practices meet one another on the meaning level, they consequently produce a dialogic relation. Nunes and Kramer (2011, p. 33, authors' emphases) claim that, for Bakhtin, language only takes place "between the self and the other, between many selves and many others," that is, multiple voices socio-historically situated intertwine in this dialogic process. Nonetheless, it is important to underline that each utterance is also unique, for it is produced in a specific time, place, situation, and among specific interlocutors.

Furthermore, Bakhtin (2003) also discusses the concept of alterity, which is related to the self and non-self, to otherness, to their formation. Regarding alterity, White (2009) states that each individual is unique and remains unfinalized, incomplete, being capable to contribute with dialogue throughout their entire life. Barros (1997), in regard with Bakhtin's ideas, underlines that alterity is one of the aspects that defines human beings, i.e. one's relations with the other hugely contribute to one's self-formation.

In addition, Brait (2005, p. 22), considering Bakhtin's ideas, points out the triad I-to-myself, I-to-the-other and the-other-to-me and, according to her, it is important to conceive the individual as a socio-historical situated subject. The first concept involves the individual's subjective identity, that is, how one conceives oneself; the second concept has to do with how the others see the self; and the third concept emphasizes how I see the other. It is between these relations that human beings construct what they understand about their own reality. 
Figueredo (2007) comments on the multifaceted aspect of language, also on its heterogeneity of discourses that create its polyphonic aspect - many voices dialoguing in the same utterance - contributing to the phenomenon of enunciation. Figueredo (2011) asserts that it is through a dialogic and discursive practice that individuals show their subjectivity, exposing their understanding of themselves and of the world around them. Furthermore, the author mentions that in each utterance, the individual exposes their individuality, but also the voices of the social context which are intermingled with their own voice.

\section{Vygotskian sociointeractionism}

According to Rego (1995) e Vygotsky (1978) conceives culture as an aspect that constitutes humans beings, something that is acquired, learned by them, especially mediated by language. They are not born with it, but are rather prone to acquiring it. Thus, individuals take part in social-historical contexts that assist them in developing their superior psychological functions. It is important to mention that, for Vygotsky (1978), the superior psychological functions arise first in the social level (or interpersonal relations) to reach the intrapsychological level afterwards. Hence, Rego (1995) mentions the dialectical interaction between human beings and the socio-historical and cultural contexts that surround them. Therefore, it is understood that subjects change their environment, the context they live in and are changed by them. Thereby, they also play an active role in the process. Vygotsky (1978) discussed the significant roles of cultural mediation and interpersonal communication, commenting on the shared knowledge of a culture, which results in the process known as internalization.

According to Spirkin (1983, apud LANTOLF; APPEL, 1994, p. 4), "[c]onsciousness arises, functions, and develops in the process of people's interaction with reality, on the basis of their sensuously objective activity, their socio-historical practice." Rego (1995) comments on language as a substantially mediating tool, which enables the interaction among individuals, carrying in it the human culture, its history, its essence. The latter author highlights that it is 
through this interaction with the world and with other human beings that the subject learns how to behave socially and deal with everyday life, thus developing their own understanding of oneself and of others as well as their understanding of the world.

Rego (1995, p. 55) emphasizes that "internalizing the systems of culturally produced signs provokes crucial changes in the human behavior," and it is through the interaction with others that those changes take place. She also underlines that it is in the socio-cultural context where the subjects' sociocognitive development occurs. The individual affirms their individuality from their relations with the other, formed in this social, dynamic and dialectical process, which all human beings are a part of.

For Vygotsky, as Rivière observed (1984, apud MOLL, 1990, p. 1-2, author's emphasis), "schools (and other informal educational situations) represent the best 'cultural laboratories' to study thinking: social settings specifically designed to modify thinking." Moll (1990, p. 8) highlights the "creation of social contexts in which [students] actively learn to use, try and manipulate language in the service of making sense or creating meaning." Thus, the same author states that

[t]he role of the teacher in these social contexts is to provide the necessary guidance, mediations, in a Vygotskian sense, so that [...] [students], through their own efforts, assume full control of diverse purposes and uses of oral and written language. (MOLL, 1990, p. 8-9)

Thereby, according to Vygotsky (1984, apud REGO, 1995), learning is important because it is from it that the subject's individual and social development takes place. For him, the individual participates in an ongoing process of deconstruction, reconstruction and construction of his/her own socially, historically and culturally situated being.

\section{The zone of proximal development (ZDP)}


The zone of proximal development (ZDP) concerns the idea of the distance between what one can do with help and without it by taking into account the social dimension, which provides symbols and tools that mediate the relation of the individual with the world, as Rego (1995) points out. According to Vygotsky (1978, p. 86),

[it] is the distance between the actual developmental level as determined by independent problem solving and the level of potential development as determined through problem solving under [...] [somebody's] guidance or in collaboration with more capable peers.

The study of the zone of proximal development linked to the teachinglearning process is relevant because it regards one's individual socio-cognitive development. Vygotsky (1981, apud MOLL, 1990, p. 11) "claimed that intellectual skills children acquire [are] directly related to how they interact with [one] [an]other in specific problem-solving environments." Rego (1995, p. 73) points out that schools tend to primarily take into account the level of actual development, which is defined as "what the learner can do by himself/herself, without any help." Therefore, the student is assessed based on what $\mathrm{s} / \mathrm{he}$ can do without another person's collaboration, and that represents one's development, thus neglecting one's potential development.

From that, Rego (1995) underlines that the teaching-learning process is the one responsible for providing all necessary means to create the zone of proximal development. This scaffolding process ${ }^{5}$ consists in the support given by the teacher/instructor or a more capable peer in order for the learner to solve something. Thereby, the concept of scaffolding is related to the zone of proximal development, as Vygotsky (1978, p. 37) underlines that social interaction is a "mechanism for individual development, since, in the presence of a more capable participant, the novice is drawn into, and operates within, the space of the expert's strategic processes for problem solving." From the social context the learner is a part of, from their interactions with other peers, $\mathrm{s} /$ he will first develop

\footnotetext{
${ }^{5}$ Wood, Bruner and Ross (1976) were the first authors to use the metaphor of scaffolding as meaning the concept of support and guidance in the teaching-learning process.
} 
activities with someone's help, but will internalize the processes used to achieve them afterwards.

According to Moll (1990, p. 12), "from a Vygotskian perspective, a major role of schooling is to create social contexts (zones of proximal development) for mastery of and conscious awareness in the use of these cultural tools." Once students have acquired the capacity to do something by themselves, by doing it previously with someone's assistance, changes will also happen in their superior psychological functions. Acunha (2011) adds that, in the zone of proximal development, the main role a teacher must perform is to be a mediator between his/her students and the objective world.

\section{Learner autonomy from a Freirean perspective}

Freire (2005) criticizes that very often educators deal with education as a banking system, in which students are frequently perceived as blank slates, where teachers deposit their knowledge. He laments the fact that in this "distorted view of education, there is no creativity, there is no transformation, there is no knowledge" (FREIRE, 2005, p. 67). Besides that, he states that this banking conception of education "negates dialogism as essence of education, making it anti-dialogic" (FREIRE, 2005, p. 78). According to him, learner and teacher should bear in mind that "to teach is not to 'transfer knowledge', but to create possibilities for its production or construction" (FREIRE, 1996, p. 22, author's emphasis). The author claims that human beings are historical and unfinished beings.

Freire (1996) emphasizes the importance of not only teaching contents, but also teaching students to have a critical reflective thinking. He asserts that what is taught in schools distances itself from students' realities. Thus, the author underlines the importance of valuing students' previous knowledge and experiences.

Scrivener (1994, p. 4) underlines that "people learn more by doing things themselves rather than being told about them". When one learns to be autonomous, one learns to learn by oneself. Freire (1996) conceives education 
as a transformative practice, which should lead to autonomy and liberation. He claims that teachers need to recognize their students as socio-historical and cultural subjects. Thus, he defends that "[it] is fundamental that teacher and students know that their posture is 'dialogic', open, curious, inquiring and not made passive, while one talks and another listens" (FREIRE, 1996, p. 86, author's emphasis).

Freire $(1996,2005)$ sees the ethical nature of the educational practice and asserts that teachers should understand education as a political ideological act, that is, teachers need to have a critical reflection upon their work. In other words, educators need to grasp that they are not just training students, but that they are rather participating in the process of those subjects' education, with the responsibility of playing a major role in their students' lives. Freire (1996) adds that knowledge is not ready; on the contrary, it is built through interactions in the classroom.

\section{A dialogue between Bakhtin, Vygotsky and Freire}

Bakhtin (1993, 2003), Vygotsky (1978) and Freire (1996, 2005) are authors that in general follow the principles based on dialectical materialism. This philosophical conception considers that human beings shape their environment and, at the same time, are shaped by it. Therefore, the natural, the social and the psychological worlds are connected in a dialectical process. Acunha (2011) states that these authors regard language as an instrument of symbolic mediation, which is central to social interactions as well as to the teachinglearning process. They consider language "not only as expression of thought or means of communication, but as interactions among socio-historically situated subjects" (ACUNHA, 2011, p. 7). All three authors, according to Petroni and Souza (2009), affirm that it is through these interactions, through the social relations that the individual has with others that $s / h e$ is constituted and produces knowledge.

The idea of autonomy defended by Freire (1996) is quite close to Vygotsky's (1978) understanding of self-regulation, for it is in the social 
interactions that children learn and understand the symbolic world and learn how to behave socially, building also their cognitive processes, that is, their interpsychological as well as their intrapsychological levels are developed. Therefore, the environment plays a very important role in the development of students' autonomy and self-regulation. Bakhtin (1993, 2003), Vygotsky (1978) and Freire $(1996,2005)$ consider the mediation of the other essential for such processes to take place. Acunha (2011, p. 10) highlights that

\footnotetext{
[i]f Vygotsky innovates bringing concepts like mediation, internalization, the zone of proximal development (ZPD), Bakhtin and Freire reiterate these concepts by emphasizing the importance of society, culture, exchanges, so there is this mediation, in order for the ZPD to be triggered.
}

Marques and Oliveira (2005, apud PETRONI; SOUZA, 2009, p. 355-356) affirm that, regarding education, what Freire (2005) called the banking system, Vygotsky (1978) named the old school. Both perceptions, as well as Bakhtin's (1993), refute the idea of education as "the simple transmission of knowledge, the way of seeing the subject as individual, ahistorical, as if one's knowledge were not also cultural and one were not embedded in a society" (MARQUES; OLIVEIRA, 2005, apud PETRONI; SOUZA, 2009, p. 355-356). Therefore, for these authors, the individual is a socio-historical, political and cultural being who plays an active interactional role in their relationships with the world and with other people. Hence, as schools are perceived as social settings as well, this very idea applies to them too.

In the following part, we present the methodology used in order to carry out this study, as well as the context, research participants and data generation instruments and procedures.

\section{The study}

In order to conduct this investigation, this study is drawn upon qualitative research linked to tenets of the interpretivist paradigm, more precisely, actionresearch, which is built on discussions and interpretations of the data generated. In qualitative research, taking into account that each context is unique, there is 
no way to generalize results. Thus, social practices and their meanings are the main aspects addressed (BORTONI-RICARDO, 2009; MELLO; REES, 2011).

More specifically, action research was the choice made to develop this investigation. Particularly, in the educational area, teacher-researchers use action research in order to improve their teaching, their own practice and their students' learning. Tripp (2005) mentions four basic phases, which compose a cycle of action inquiry:

a) planning an improvement to make researchers' practice better, that is, in this context, to make teachers' own practice better;

b) implementation, which is the act of carrying out the planned interventions;

c) description, as regards the observation and writing in detail about the effects of the interventions made; and

d) evaluation of outcomes after the interventions (which in the case of action research is compulsory).

All these phases were carried out in this research. Although the study was conducted with a third-year group of thirty students from a state school, not all students were present when the questionnaires were handed out and not all of them gave the authorization documents back ${ }^{6}$. Therefore, as only twelve students answered the initial questionnaire and gave the authorization documents back, the data provided by them were the ones analyzed, in the first subsection of the data analysis. The questionnaire was used to outline and provide a profile of the group researched as well as their experiences, perceptions and opinions (NELSON et al., 1992, apud DENZIN; LINCOLN, 2003; MELLO; REES, 2011) concerning the English language and their English classes (Appendix A).

In addition, during the interventions, the teacher-researcher kept field notes, which are also considered in this study, and a final interview was done

\footnotetext{
${ }^{6}$ Prior to the generation of data, all necessary documentation was signed by the participants (assent forms by the students and informed consent forms by their parents or legal guardians), as well as the statement of consent by the institution. As in the study no information that can identify the state school and the participants is exposed, there is no risk concerning the identification of those involved.
} 
with six students (Appendix B). The criteria used to select the participants who were interviewed were students' presence in class, that is, who attended most lessons. Thus, six students, namely five girls and one boy, who had attended at least five classes and had given their authorizations papers back, were invited to participate in the individual interviews. After all interventions, we resorted to the semi-structured interview in order to verify the students' perceptions and opinions about the English lessons taught by the teacher-researcher. All excerpts generated from interviews are in Portuguese due to students' low level of proficiency in English.

Seven classes were taught in order to carry out this study. It is relevant to point out that the lessons were given in the school auditorium, which is a place where there is a structure that enabled a change in the arrangement of desks, allowing the arrangement of a circle instead of rows. In the next section, we discuss and analyze the data generated from questionnaires, field notes and interviews. We highlight that the transcriptions were not made verbatim, for our interest is the content, and not the linguistic structure. Formal adjustments were made, when necessary, to provide a more fluid reading, in a way that the participants' discourses were not changed.

\section{Data analysis}

In the following subsections, firstly, we analyze and discuss the students' experiences, first perceptions and opinions concerning English as well as English lessons, based on answers provided in the initial questionnaire by twelve students, before the interventions. Secondly, we address the English classes during and after the interventions, focusing on the teacher-researcher's descriptions and perceptions of the lessons, from field notes, and the experiences, perceptions and opinions of six students about their English classes, from interviews, after the interventions. The analysis of the English classes during and after the interventions is divided into three topics: the process of interaction; the importance of the other in the learning process; and teaching English in public schools. 


\section{Students' experiences, first perceptions and opinions about English}

From the twelve students who answered the questionnaires, seven are girls and five are boys, and their ages ranged from 16 to 19 . Among them, only three answered the questionnaires and also did the interviews. The other three learners who did not answer the questionnaires, but were interviewed, were the ones who attended at least five out of the seven classes given. Therefore, in this subsection, this group of twelve students was chosen to represent the third-year group who took part in the investigation. Firstly, as it can be seen in Table 1, from the twelve students who filled out the questionnaire, ten had English classes in elementary school, two had it in language schools and one had lived abroad.

Table 1 - Students' experience with English

\section{2}

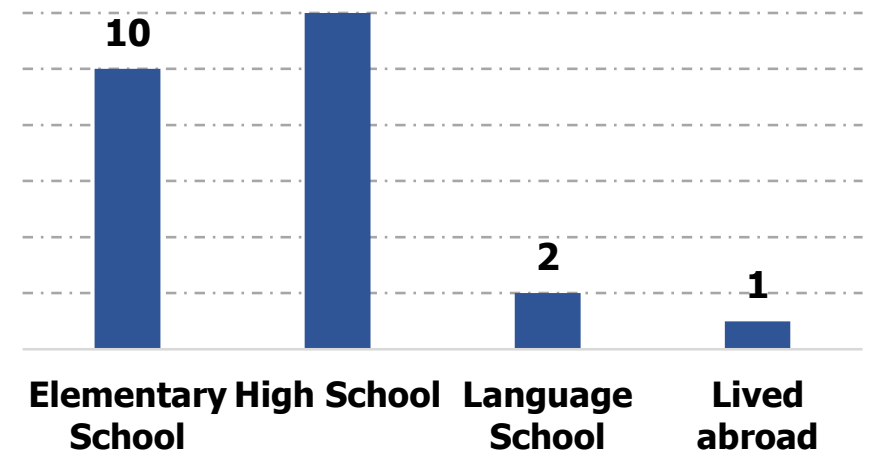

When inquired what their classes were like, most students mentioned the writing and reading skills, translation and grammar, respectively, concerning the skills and aspects their former teachers most worked with. As in most public schools, the listening and speaking skills are shown as neglected as well as the interaction in classes among students and teacher using the language they would supposedly learn. It must be taken into account that these answers concern not only public schools, but also all other sites in which students studied English. See Table 2. 
Table 2 - What students' clapses were

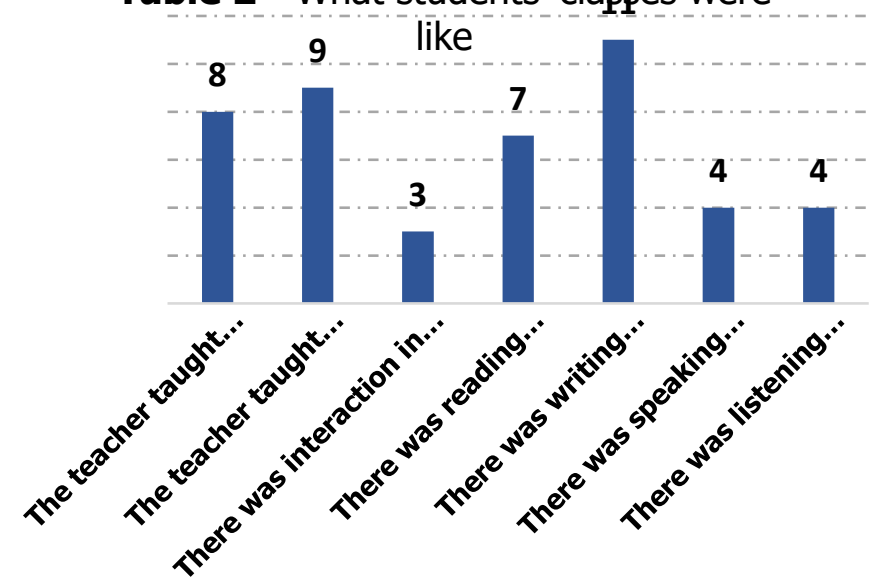

That kind of teaching is often perceived by students as mechanical (BARCELOS, 2006), for if students are supposedly learning a language, but they are not able to use it in order to interact with each other, so consequently it is unlikely that learning such language is going to make any sense to them. Table 3 basically reinforces the information shown in Table 2.

Table 3 - Students' familiarity with the skills

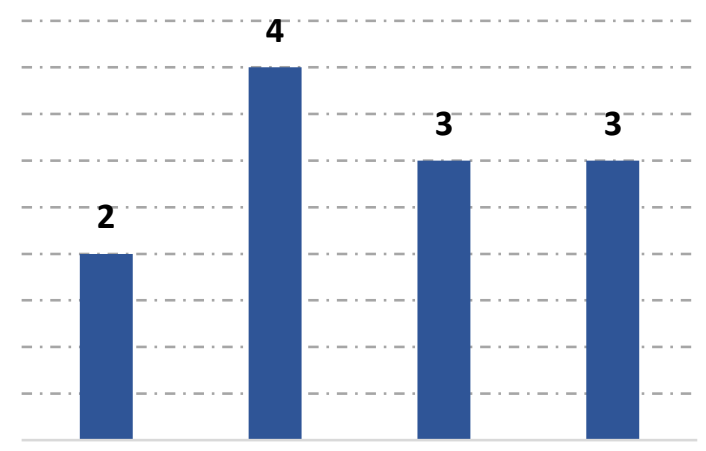

\section{Speaking Writing Reading Listening}

In their questionnaires, the students asserted that they would like to listen to the language and to speak it. Thus, as Barcelos (2006, p. 157) emphasizes, "the public school [is perceived] as a place where students' expectations in relation to English [...] are not fulfilled." They claimed that they would enjoy lessons in which the teachers could use songs, movies and games to enrich their learning. They would also like classes to be more dynamic and that their teachers interacted with them more often. They complained about their teachers' 
methodologies and way of explaining contents that, according to them, make the learning process harder.

Table 4 - Students' feelings towards English

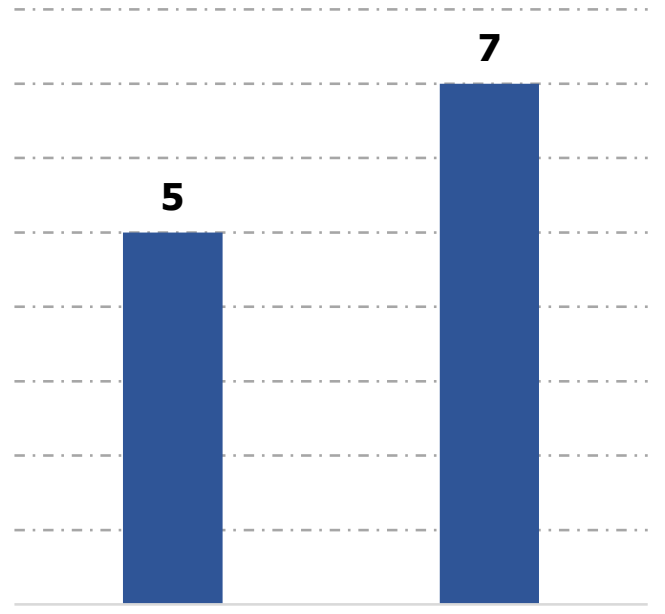

Like

Do not like

All students asserted that they consider important to study English, although most affirmed not to like it (Table 4). They mentioned that English is present in their lives and that they may need it professionally, socially, for studying and for leisure. Some stated they have interest in learning the language because they like it or because of the labor market. The ones who do not like it affirmed they perceive English as a difficult language to understand and learn. As Barcelos (2006, p. 155) underscores, students' experiences with their English language classes are often characterized as "bad and demotivating," and that influences their interest towards the language.

\section{The English classes during and after the interventions}

In this subsection, we address the teacher-researcher's descriptions and perceptions as well as the students' experiences, perceptions and opinions about their English classes, during and after the interventions. As we present individual 
statements of six students who were interviewed, Table 5 provides their pseudonym, sex and age:

Table 5 - Students interviewed

\begin{tabular}{|c|c|c|}
\hline Pseudonym & Sex & Age \\
\hline Paola & F & 19 \\
\hline Paulo Vitor & F & 17 \\
\hline Yasmim & F & 16 \\
\hline Cris & F & 16 \\
\hline Mel & F & 16 \\
\hline Rodrigo & M & 16 \\
\hline
\end{tabular}

The interaction process, the importance of the other in the learning process and teaching English in public schools are the topics that are addressed. Scrivener (1994) underlines that when teachers include many interactive activities among students, use recordings in order to provide different sources for students to listen to other people speaking, and prepare at least one game each class that involves students moving around the classroom, such educators probably believe that:

a) providing opportunities for students to speak is important;

b) students learn by trying things;

c) promoting fluent use of the language is essential;

d) learners have the chance to know one another better;

e) it is relevant to listen to different people and not only to the teacher;

f) students should learn English with real interactive activities; and

g) sitting in the same place for a long time is not a good idea, so change and variety are important aspects.

All classes given were conducted based on these beliefs, actions and attitudes. Bakhtin's (1993, 2003), Vygotsky's (1978) and Freire's (1996, 2005) ideas support such presuppositions because, for these authors, interaction is essential for students to develop their socio-cognitive processes as well as their language learning. Listening and speaking are important skills that assist them in it. Besides that, trying plays a significant role insofar it is by attempting that individuals learn. In addition, moving around to get into contact with different 
people is advantageous as well, because as Scrivener (1994, p. 13) underlines, "varying groupings is one way of enabling a variety of experiences for the learners."

\section{The process of interaction}

The activities done in class had as their overall aim, as Scrivener (1994, p. 3) points out, "to allow [...] students practical experiences in doing things (e.g. in using language)", giving them "opportunities to do things themselves." The following excerpt shows some of the teacher-researcher's perceptions regarding the classes she was teaching:

\section{Excerpt 01}

After learning the verb be and its affirmative, negative and interrogative forms ${ }^{7}$, the learners did the activity find someone... (Are you...? Yes, I am/No, I'm not), which is very interactive, as they had to walk around the classroom, asking each other questions about their personal lives. They laughed a lot while trying to talk in English, and also helped each other to pronounce the words, to understand the questions, to carry out the activity. They had fun while doing the activity. I could see that learning English was finally starting to make sense to them, as they were using it to interact with each other. (Field notes, fifth class, 14 April 2014)

In excerpt 01 , the teacher describes how the students were helping each other by means of interacting with one another. Because they could communicate in English, sharing their personal experiences and information regarding their lives, it was perceivable that they enjoyed carrying out the activity. In the sequence, one excerpt from an interview with a student corroborates what the teacher-researcher stated in the previous excerpt.

\section{Excerpt 02}

Teacher-researcher: $\mathrm{O}$ que você achou da atividade verb be (affirmative, negative, interrogative)? Mel: Bom, em geral, na sua aula, eu gostei, porque é diferente de todas as aulas de inglês que eu já tive, desde a $5^{a}$ série, porque as aulas de inglês que a gente tem na escola, em geral, são muito monótonas [...] e, a sua aula é dinâmica e isso ajuda mais no ensino das pessoas. Eu mesma aprendi muito mais com as dinâmicas, [...] do que apenas aquela coisa muito monótona na sala, entendeu? Assim, ajuda muito mais nosso aprendizado. A gente pôde brincar. Eu gostei muito! $^{8}$ (Interview, question 1 , letter a, 12 May 2014)

\footnotetext{
${ }^{7}$ The description of the activity carried out can be seen in Appendix C.

${ }^{8}$ Translation: What did you think of the activity verb be (affirmative, negative, interrogative)? Mel: Well, in general, in your class, I liked because it is different from all other English classes I have ever had, since $5^{\text {th }}$ grade, because the English classes that we have at school, in general, are monotonous [...] and your class is dynamic and that helps people to learn. I learned much more with the dynamic activities [...] than only with that very monotonous thing in the classroom, you see? So it helps much more our learning. We could play. I liked it a lot!
} 
In excerpt 02, Mel mentioned that prior to the lessons taught by the teacher-researcher, her classes were monotonous, boring and dull. Freire (2002, apud MARQUES; MARQUES, 2006) criticizes this kind of teaching in which educators simply deposit what they know in the recipient-students, leading them to a mechanical memorization of contents that, in the end, makes no sense to their lives. Nunes and Kramer (2011) claim that instructors who perceive students as passive beings end up conveying the idea of a kind of teaching which is meaningless to the learners, for it seems that knowledge is not constructed socially and that learners are individuals who participate in the process only externally, that is, there is no active role for students to play.

When asked about the lessons, in excerpt 02, Mel compared the classes she had had previously to the ones she had with the teacher-researcher. She described them as dynamic, interactive, playful and fun. Freire (2005) understands education as a dialogic process in which both the teacher's and the students' voices are taken into account. The feeling of belonging, of playing a crucial role in the process, is necessary in order to make visible the importance of educators as well as learners. Marques and Marques (2006) highlight that education must be necessarily a dialogic process so it can succeed. According to Lantolf and Appel (1994), the social context plays a dynamic role in the students' learning process. The classes given clearly conceive individuals as active agents, who are responsible for the construction of their knowledge.

The speaking and listening skills are often neglected in public schools. However, in this investigation, such skills were worked with in the lessons given by the teacher-researcher. Paola, in excerpt 03, and Yasmin, in excerpt 04, mention how the experience was.

Excerpt 03

Teacher-researcher: 0 que você achou da atividade find somebody who...? ${ }^{9}$

Paola: Foi bom, porque colocou a gente para falar mesmo, expressar mesmo o inglês e interagir com as outras pessoas. ${ }^{10}$ (Interview, question 1 , letter b, 12 May 2014)

${ }^{9}$ The whole activity can be seen in Appendix D.

${ }^{10}$ Translation: What did you think of the activity verb be (affirmative, negative, interrogative)? 
Excerpt 04

Teacher-researcher: $\mathrm{O}$ que você achou da atividade find somebody who...?

Yasmin: Foi interessante também, porque a gente aprendeu mais sobre os outros alunos. ${ }^{11}$ (Interview, question 1, letter b, 12 May 2014)

In excerpt 03, Paola emphasizes that, by speaking, interaction among everyone that was in class took place. Besides, in excerpt 04, Yasmin asserts that through the activities, through interaction, she could learn about other people. Taking into account Bakhtin's, Vygotsky's and Freire's ideas, Nunes and Kramer (2011, p. 40) claim that classrooms are the site for "real verbal interactions of dialogues between teachers and students, among students, and dialogue with knowledge: environment-school socio-cultural-life articulation." In addition, in our research, as it can be perceived from the students' excerpts, the speaking skill was highly emphasized because, as Acunha (2011, p. 2) points out, "[it] is fundamental to social interaction[s] and to the exchange of experiences" among learners.

\section{The importance of the other in the teaching-learning process}

Below, in excerpt 05, we present some reflections from the teacherresearcher and, in excerpts 06 and 07, from Mel and Paulo Vitor, respectively, in order to discuss the presence of the other in the teaching-learning process:

\section{Excerpt 05}

On this day, I mainly worked with the listening and speaking skills. Students listened to recordings and were asked to work in small groups (from three to four people) in order to complete and create conversations like the ones they listened to. I could see that while doing the activity, they helped each other with new words, pronunciation, organization of ideas, etc. They were teaching and learning together. At the same time, they were assuming different roles - teaching their classmates and learning with them. (Field notes, third class, 31 March 2014)

Excerpt 06

Teacher-researcher: $\mathrm{O}$ que você achou da atividade find somebody who...?

Mel: Foi muito boa aquela aula, porque ela ensinou a gente. Aí, todo mundo falando errado em inglês, né? Mas, não! Um ensinava o outro como é que dizia tal palavra, aí a outra pessoa respondia em inglês, a gente já aprendia aquela palavra e a gente anotava em inglês. Aí

Paulo Vitor: It was good because it made us speak for real, to express ourselves in English and interact with other people.

${ }^{11}$ Translation: What did you think of the activity verb be (affirmative, negative, interrogative)?

Yasmin: It was interesting as well because we learned more about the other students. 
perguntava para a senhora como é que escrevia em inglês, né? Foi muito boa aquela aula, porque a gente soube conversar com os outros em inglês, brincar e a gente até aprendeu a falar corretamente, né? ${ }^{12}$ (Interview, question 1, letter b, 12 May 2014)

\section{Excerpt 07}

Teacher-researcher: Em relação às atividades desenvolvidas em sala, como foi a interação entre professora e alunos? Entre alunos e professora? Entre alunos e alunos?

Paulo Vitor: A gente interagiu, a gente conversou bastante, trocou muitas ideias. Então, foi uma troca de conhecimentos. ${ }^{13}$ (Interview, question 5, 12 May 2014)

Moll (1990) emphasizes that the interactive teaching-learning process, the dialogue, precisely characterizes the zone of proximal development. Therefore, when students can help each other, they learn together and this makes the process easier. What the teacher-researcher and Mel pointed out, in excerpts 05 and 06, respectively, is that "[...] learners are capable of providing guided support to their peers during collaborative L2 interactions" (DONATO, 1994, p. 51). Greenfield (1984, apud DONATO, 1994, p. 40) underscores that

[i]n social interaction a knowledgeable participant can create, by means of speech, supportive conditions in which the novice can participate in, and extend, current skills and knowledge to higher levels of competence.

Donato (1994) underlines that in a scaffolded performance students coconstructed their knowledge through shared activities, working collaboratively. Lantolf and Appel (1994) claim that students rely on dependency on other peers and then, they become independent, being able to use semiotic tools by themselves. Paulo Vitor's statement, in excerpt 07, shows how the zone of proximal development and the scaffolding process had a huge importance in order for them to develop their knowledge concerning English as a means of

\footnotetext{
12 Translation: What did you think of the activity find somebody who...?

Mel: That class was very good because it taught us. So everyone was speaking in English incorrectly, right? But, no! One taught the other how to say such word, so the other person answered in English, we learned that word and wrote it in English. So we asked you, ma'am, how we could write it in English, right? That class was very good because we could talk to each other in English, play and we even learned how to speak correctly, right?

${ }^{13}$ Translation: In relation to the activities done in class, how was the interaction between teacher and students? Between students and teacher? Among students and students?

Paulo Vitor: We interacted, we talked a lot, we exchanged many ideas. So it was a knowledge exchange.
} 
communication. Besides that, we can also see how the other (the partner in the classroom activity) plays a crucial role not only in the dialogic process of the language use, but above all, in the construction of students' subjectivity. They were then able to recognize the relevance of collaboration to the language teaching-learning process as well as the necessity of seeing language as a living entity (BAKHTIN, 2003).

In excerpt 08, we show some of Rodrigo's words concerning how he perceived the presence of the other in the English classes taught by the teacherresearcher:

\section{Excerpt 08}

Teacher-researcher: Em relação às atividades desenvolvidas em sala, como foi a interação entre professora e alunos? Entre alunos e professora? Entre alunos e alunos?

Rodrigo: Foi quase somente aluno com aluno, né? Foi mais com o colega ao invés de professor com aluno. [...] Lá no auditório, foram bem melhores as conversas. As atividades não foram individuais. Foi para a sala toda resolver. Então, fez a gente se unir mais. ${ }^{14}$ (Interview, question 5, 12 May 2014)

Moll (1990) highlights the mediator role the instructor should perform in order to lead students, but in a way that they can learn how to do the activities by themselves, taking control of language with their own effort. This concept is closely related to Freire's autonomy (1996) and Vygotsky's idea of self-regulation (1978) that individuals must develop. Harmer (1998, p. 4) claims that "getting students to speak - to use the language they are learning - is a vital part of a teacher's job." In the excerpt 08, Rodrigo mentioned he could conceive the activities done as a means of communicating with other people. Rodrigo even claimed that the activities helped them to improve their relationships within the group, collaborating to bring them closer to each other, to get to know their classmates.

\footnotetext{
${ }^{14}$ Translation: In relation to the activities done in class, how was the interaction between teacher and students? Between students and teacher? Among students and students?

Rodrigo: It was almost only student with student, right? It was more with the classmate than the teacher with students. [...] There, in the auditorium, the conversations were much better. The activities were not individual. It was meant for the whole group to solve. Then, it made us come closer together.
} 


\section{Teaching English in public schools}

Finally yet importantly, we exhibit some reflections on teaching English in public schools by resorting to the teacher-researcher's field notes, in excerpt 09, and to Chris' words, in excerpt 10:

Excerpt 09

This experience showed me that it is actually possible to teach English in a public school, not much (because of the restricted time for classes and institutional and infrastructural constraints), but something. (Field notes, third class, 31 March 2014)

Excerpt 10

Teacher-researcher: O que você achou da atividade find somebody who...?

Cris: Eu achei que foi uma dinâmica proveitosa também, porque a gente acabou interagindo de uma forma mais ampla e usando o que a gente aprendeu. A gente não deixou lá só guardado. A gente acabou usando também e aproveitando, né? Então, fica na cabeça quando a gente usa. ${ }^{15}$ (Interview, question 1, letter b, 12 May 2014)

As students could effectively use language to interact with each other that shows they could consciously manipulate a symbolic system (MOLL, 1990), in relation to the activity led by the teacher. That corroborates the teacherresearcher's words, in excerpt 09. Through those activities, students could understand and express meanings by using English, constructing such meanings by themselves during the interactions. As Almeida Filho (1993) claims, when students are engaged in real interactions in classroom, when they are able to construct meaning by interacting with others, then learning a foreign language makes sense to them.

For Bakhtin (1993), interaction is one of the fundamental aspects when it comes to language. Subjects construct one another in the act of communication, in the act of interaction. For Vygotsky (1994, apud ARAÚJO; VIEIRA; CAVALCANTE, 2009, p. 5), "it is the inclusion of relations among people that ensures learning. [...] It is the interaction among people that provides the development of thought and language." Figueredo (2007) highlights the

15 Translation: What did you think of the activity find somebody who...?

Cris: I thought that it was a useful dynamic activity as well because we ended up interacting in a broader way and using what we had learned. We did not keep it only there stored [in our minds]. We ended up using it and enjoying it as well, right? So we keep it in mind when we use it. 
importance of interaction and dialogue in the construction of the social and cultural environment, which the subjects take part in.

In excerpt 10, Cris claimed that she could use what she had learned, experienced, which she could not apparently experience before. Her discourse exposes that there is a lack of using what students study. Hence, it is possible to affirm that students' teaching-learning process will only make sense to them if indeed they can use what they study.

\section{Final considerations}

In the introduction, three questions that guided this study were asked:

a) Which are the learners-participants' perceptions regarding the teachinglearning process of English, before and after the interventions?

b) How can different forms of social interaction (T-S, T-Ss, S-T, S-S, SsSs, Ss-T) interfere in English classes of a third-year group from a state school?

c) How does the teacher-researcher perceive the experience of teaching English with its focus on social interaction?

There were many changes in the learners-participants' perceptions regarding the teaching-learning process of English. Firstly, as students practiced the listening and speaking skills, they started conceiving them as skills that were possible to be worked with. They realized that they could understand people speaking English, and that they could also speak English. In addition, the students could recognize the learning of English not only as learning contents and linguistic aspects, but also as learning to communicate, to interact with other people. Secondly, the students perceived the importance of the other in the teaching-learning process of a foreign language. All the students interviewed highlighted that everything done in pairs, small and big groups, as well as the teacher's support, were helpful to develop their interpsychological and intrapsychological processes. That means that students noted they developed their learning with and because of the interactions with their classmates and the teacher, and that that helped them to absorb, understand and learn the content 
given. It is also important to highlight that they improved their relationship with their classmates. Thirdly and lastly, the learners pointed out that, because the atmosphere and environment of their English language classes changed, they started seeing them with different eyes, i.e. learning could be fun.

Students could perceive English as a language possible to be appropriated by them in the classroom context. From the excerpts exposed in the data analysis, students commented on their interaction with their teacher and among their classmates. They highlighted they could learn by the assistance of the other. All students interviewed claimed that the presence of other people helping them in an interactive process was crucial for their linguistic development. Students even asserted that, after the classes, the relations among them improved, for as they had to talk, as they had to interact in English in order to do the activities, they also learned about their classmates' lives. That was another aspect which was helpful in the process, for they noted an effective use of the language they were learning.

The teacher-researcher could perceive the experience of teaching English with its focus on social interaction as something that was possible to be accomplished, even in the context of public schools. According to her words, the students used English to interact with each other, through the activities proposed by her. In addition, she pointed out that they could assume different roles: they not only taught and learned English with each other, but also shared personal information and experiences among their classmates.

Lastly, it is important to state that, albeit this study generated some important data, this research was conducted at only one school, with a single group of students. That is to say, although their reality may be considered a sample of what happens in public schools, the results are limited and concern specifically to the context where the investigation was carried out. 


\section{Final words}

In this study even the arrangement of chairs was changed for the purpose of creating a different environment for learning. That is not common in regular schools. Students clearly approved the change, but for a factual change to be made, the State Department of Education would have to interfere. Unfortunately, regular classes at schools are quite different from the ones that were taught in order to develop this research. The lack of teachers' linguistic and methodological competence is a huge problem, as Almeida Filho (1992) points out. Obviously, there are many difficulties to face and deal with, but a part of the problem is the teachers' attitudes towards teaching and education. They seem to be unprepared and they leave us with the impression that they are not making much effort to change their reality in the school context. Furthermore, the government also does not help, and when it does, the help is basically insignificant as, for instance, there are programs for educators to improve their theoretical knowledge and also their practice, but there are too few incentives for teachers to participate in them. The time that should be used for educators to keep on studying does not exist, for they need to work full-time.

The study shows that learning a foreign language at public schools can be possible, but for that to happen effectively, several changes would have to be made. The time for studying the foreign language is an aggravating aspect: one class a week, and when the class happens there are solely 50 minutes. If such aspects could be changed and so the school cultures, then learning English would become part of the school routine. The students who took part in the study had a small sample of classes, which, according to their discourses, they enjoyed. If such classes had continuity during some years, a great impact on the reality of the school where the investigation was conducted could be made. However, nowadays, regarding the way the current system is, that is not a possible reality.

Although the students who participated in the research were at the end of high school, before leaving, they had the chance to see English through another perspective, that is, they could perceive English differently, as a language they could learn and use to interact and communicate with the world and with people. 
This research achieved its main goal insofar social interaction played its role of affecting people's lives by providing new learning experiences to them, not only to the students, but also to the teacher-researcher, in this case, in a very positive way.

\section{References}

ACUNHA, Deliamares Fraga. Freire, Vygotsky e Bakhtin em diálogo. Cenários, Porto Alegre, v. 1, n. 4, p. 1-13, $2^{\circ}$ sem. 2011.

ALMEIDA FILHO, José Carlos Paes de. O Professor de Língua Estrangeira sabe a língua que ensina? A questão da instrumentalização linguística. Revista Contexturas, Belo Horizonte, v. 1, n. 1, p. 77-85, 1992. . Dimensões Comunicativas no Ensino de Línguas. Campinas: Pontes Editores, 1993.

ARAÚJO, Isabela Rosália Lima de; VIEIRA, Adriana da Silva; CAVALCANTE, Maria Auxiliadora da Silva. Contribuições de Vygotsky e Bakhtin na linguagem: sentidos e significados. Debates em Educação, Maceió, v. 1, n. 2, p. 1-14, jul./dez. 2009.

BAKHTIN, Mikhail Mikhailovich. Toward a Philosophy of the Act. Vadim Liapunov (Trans). Austin: University of Texas Press, 1993. . Estética da criação verbal. São Paulo: Martins Fontes, 2003.

BARCELOS, Ana Maria. Narrativas, crenças, e experiências de aprender inglês. Linguagem e Ensino, Pelotas, v. 9, n. 2, p. 145-175, 2006.

BARROS, Diana Luz Pessoa de. Contribuições de Bakhtin às teorias do discurso. In: BRAIT, Beth. (Org.). Bakhtin, dialogismo e construção do sentido. Campinas, SP: Editora da Unicamp, 1997. p. 27-38.

BERNARD-DONALS, F. Michael. Mikhail Bakhtin: Between Phenomenology and Marxism. Cambridge: Cambridge University Press, 2001.

BORTONI-RICARDO, Stella Maris. O professor pesquisador. São Paulo: Parábola, 2009.

BRAIT, Beth. Bakhtin: conceitos-chave. São Paulo: Contexto, 2005. 
DENZIN, Norman. K.; LINCOLN, Yvonna. S. Introduction: The discipline and practice of qualitative research. In: . (Ed.). Strategies of qualitative inquiry. Thousand Oaks, CA: Sage, 2003. p. 1-45.

DONATO, Richard. Collective Scaffolding in Second Language Learning. In: LANTOLF, James P.; APPEL, Gabriela. Vygotskian Approaches to Second Language Research. Westport, CT: Ablex Publishing, 1994. p. 33-56.

ENGEL, Guido Irineu. Pesquisa-ação. Educar, Curitiba, n. 16, p. 181-191, 2000.

FIGUEREDO, Carla Janaína. Construindo pontes: a produção oral dialógica dos participantes do processo ensino-aprendizagem de inglês como língua-cultura estrangeira. 300p. Tese (Doutorado em Letras e Linguística) - Faculdade de Letras, Universidade Federal de Goiás, Goiânia, 2007.

. O falante nativo de inglês versus o falante não-nativo: representações e percepções em uma sala de aula de inglês. Linguagem \& Ensino, Pelotas, v. 14, n. 1, p. 67-92, 2011.

FREIRE, Paulo. Pedagogia da autonomia: saberes necessários à prática educativa. São Paulo: Paz e Terra, 1996.

. Pedagogia do oprimido. 42. ed. Rio de Janeiro: Paz e Terra, 2005.

HARMER, Jeremy. How to teach English: an introduction to the practice of English language teaching. Harlow: Longman, 1998.

LANTOLF, James P.; APPEL, Gabriela. Theoretical Framework: An introduction to Vygotskian Approaches to Second Language Research. In: (Ed.). Vygotskian Approaches to Second Language Research. Westport, CT: Ablex Publishing, 1994. p. 1-32.

MARQUES, Luciana Pacheco; MARQUES, Carlos Alberto. Dialogando com Paulo Freire e Vygotsky sobre a Educação. In: REUNIÃO ANUAL DA ANPED, 29., 2006, Caxambu/MG.

MELLO, Heloísa Augusta Brito de; REES, Dilys Karen. A investigação etnográfica na sala de aula de segunda língua/língua estrangeira. Cadernos do $I L$, Porto Alegre, n. 42, p. 30-50, jun. 2011.

MOLL, Luis C. Vygotsky and education: instructional implications and applications of sociohistorical psychology. Cambridge, New York: Cambridge University Press, 1990. 
NUNES, Maria Fernanda Rezende; KRAMER, Sonia. Linguagem e Alfabetização: Dialogando com Paulo Freire e Mikhail Bakhtin. Revista Contemporânea de Educação, Rio de Janeiro, v. 6, n. 11, p. 26-47, 2011.

PETRONI, Ana Paula; SOUZA, Vera Lúcia Trevisan de. Vigotski e Paulo fReire: contribuições para a autonomia do professor. Revista dialogo educacional, Curitiba, v. 9, n. 27, p. 351-361, maio/ago. 2009.

REGO, Tereza Cristina. Vygotsky: uma perspectiva histórico-cultural da educação. Petrópolis, RJ: Vozes, 1995.

SCRIVENER, Jim. Learning Teaching: a guidebook for English language teachers. Oxford: Heinemann, 1994.

THIOLLENT, Michel. Metodologia da Pesquisa-Ação. São Paulo: Cortez, Autores Associados, 1986.

TRIPP, David. Pesquisa-ação: uma introdução metodológica. Educação e Pesquisa, São Paulo, v. 31, n. 3, p. 443-466, set./dez. 2005.

VYGOTSKY, Lev Semenovitch. Mind in Society: the development of higher psychological processes. Cambridge, Massachusetts: Harvard University Press, 1978.

WHITE, Elizabeth. J. Bakhtinian dialogism: a philosophical and methodological route to dialogue and difference? New Zealand: Victoria University of Wellington, 2009.

WOOD, David; BRUNER, Jerome S.; ROSS, Gail. The Role of Tutoring in Problem Solving. Journal of Child Psychology and Psychiatry, Oxford, v. 17, n. 2, p. 89-100, 1976.

YAGUELLO, Marina. Introdução: Bakhtin, o homem e seu duplo. In: . Marxismo e filosofia da linguagem: Problemas fundamentais do método sociológico na ciência da linguagem. 12. ed. São Paulo: Editora Hucitec, 1997. p. 11-19. 


\section{APPENDIX A}

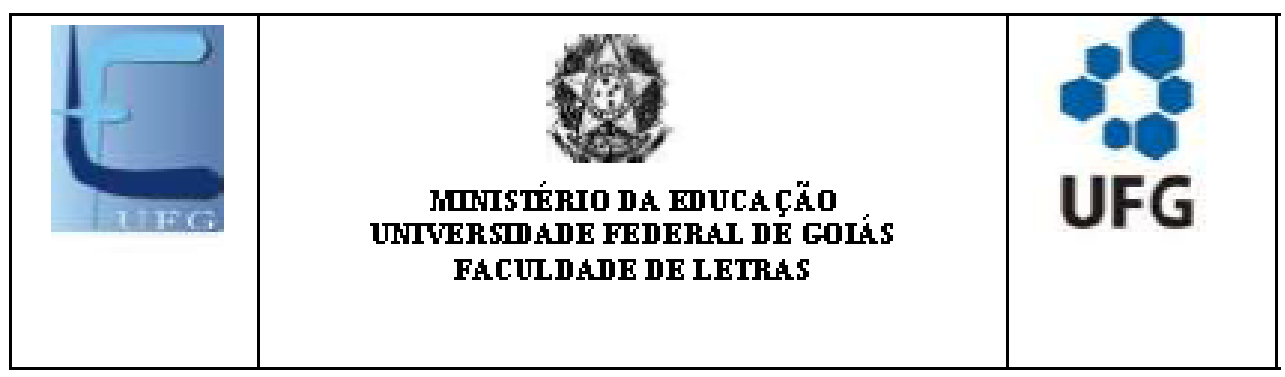

\section{QUESTIONÁRIO}

Nome:

Pseudônimo: Turno: Série: Idade:

1. Qual a sua expe iência em Língua Inglesa?

a. Ensino Furdamental ( )

b. Ensiro Médio ( )

c. Instituto de Idiomas ( ) [Onde?

d. Mbrou no exterior ( ) [Onde?

e. Outs:

2. Como eram as suas aulas de inglês? Marque as alte rativas que explicam a sua experiência.

a. Oprofessor ensinava gramática. ( )

b. O professor ensinava tradução. (

c. Havia inte ração em inglês entre os alunos. ( )

d. Havia práticalensino de leitura. ( )

e. Havia práticalensino de escrita. ()

f. Havia prática da fala. ( )

g. Havia rática da compreensão oral. ( )

3. Com quais habilidades você se considera mais familiarizado?

a. Habilidade da fala. ()

b. Habilidade da escrita. ( )

c. Habilidade da leitura. ( )

d. Habilidade da compeensão oral.( )

4. Comovocê avalia sua motivação com relação ao inglês?

a. Gosto muito de inglês e

b. Nắo gosto de inglês e

5. Em sua opirião, estudar inglês é importante? Por quề?

6. O que você acha que deveria ser feito para que as aulas de inglês fosem me lhores? 


\section{APPENDIX B}

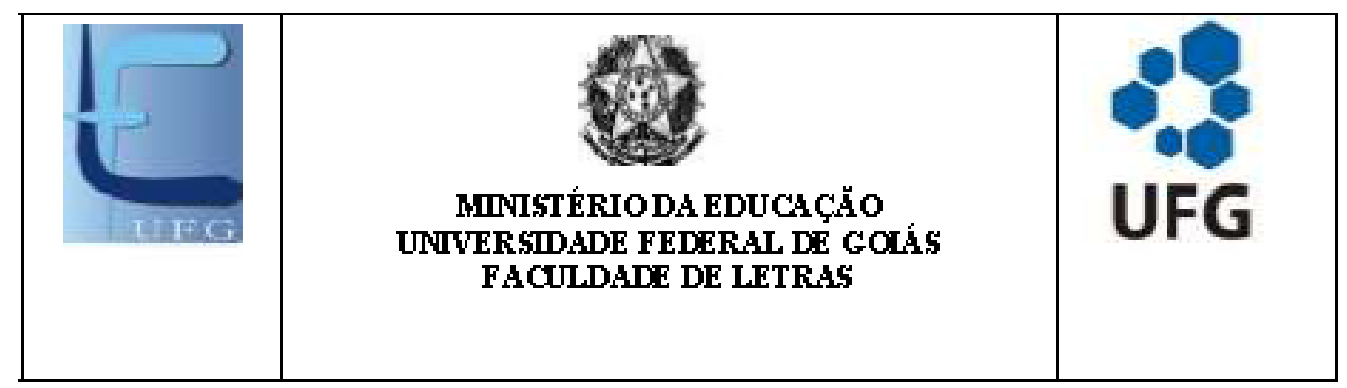

Entrevista para o p rojeto: Os impactos causados peh interação social no processo ensinto-ap rendinagem de inglês co mo LE (lingua estrangeira) em uma escola púb lica

\section{PERFIL DO ENTREVISTADO}

Nome:

Pseudônimo: Tumo: Série: Idade:

\section{PERGUNTAS DA ENTRE VISTA}

(Sinta-se à vontade para fal ar tanto quanto queira).

1. O que você achou das seguintes atividades:

a) Verb be (affirmative, negative, interrogative), dia 24/02?

b) Find somebody who..., dia 14/04.

c) Numbers, dia $28: 04$.

d) Review class and celebrity's game, dia 05/05.

2. Como você se sentiu ao desenvolver as atividades?

3. Quarto às habilidades lingús sticas, houwe prática de: (Em caso positivo, de que forma?)

() leitura () escrita ( ) compreensão oral () fala

4. O que você achou do ambiente físico da sala de aula?

5. Em relação às atividades desenvolvidas em sala, como foi a inter ação entre professora e alunos? Entre alunos e prof essora? Entre alunos e alunos?

a) De que forma essa inter ação contribuiu par a a sua aprendizagem?

6.0 que você pôde aprender nas aulas?

7. O que você pode afirmar sobre o seu próproio de senvolvimento indivichal a partir das aulas de inglês? 


\section{APPENDIX C}

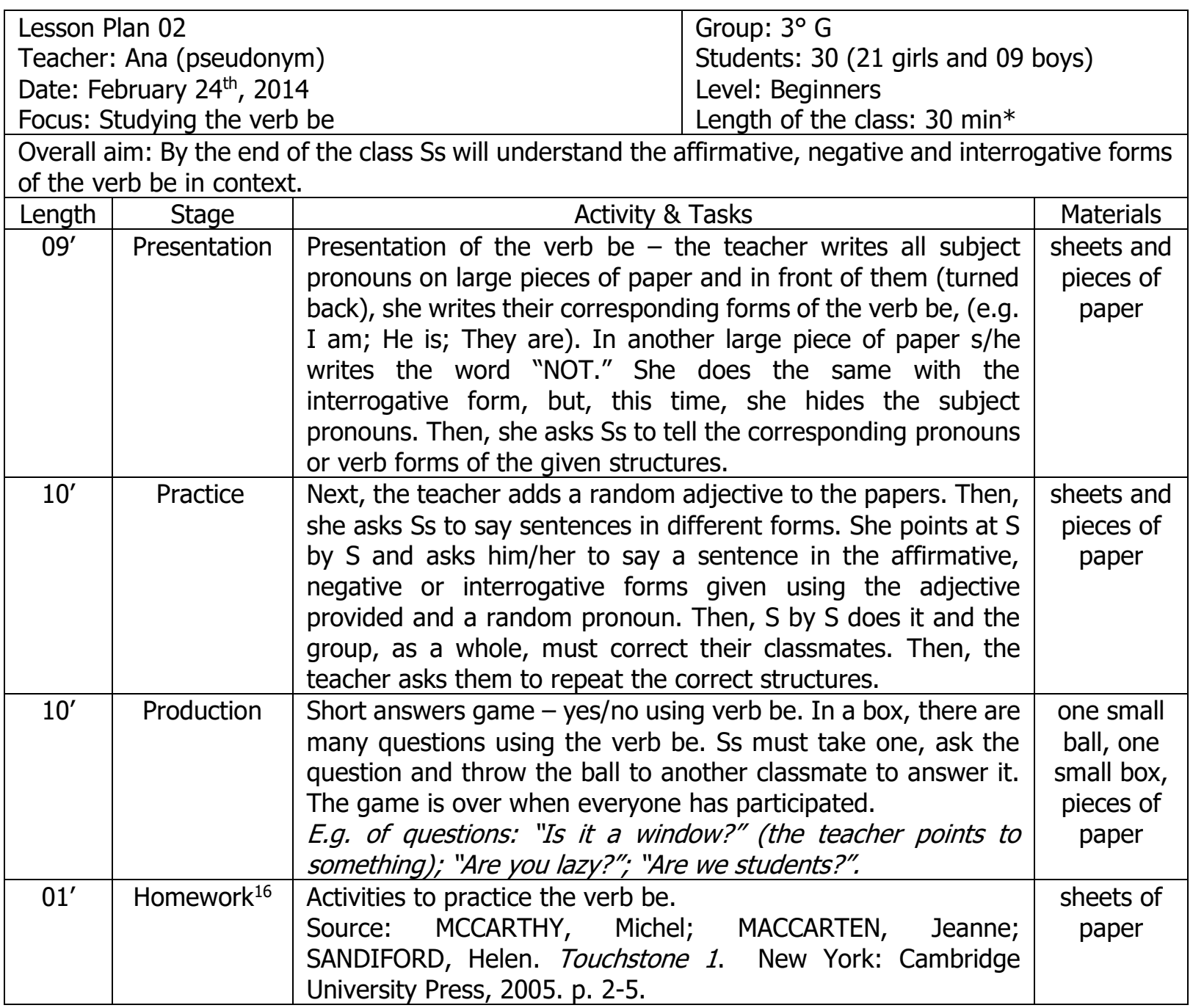

* The class ended before the regular time because "it was going to rain," said the woman who rings the bell.

\footnotetext{
${ }^{16}$ Ss were asked to acquire a material left in the school photocopier for the following classes because the book of the third year the school provides was not in accordance with the Ss' level.
} 
The importance of social interaction activities in the teaching-learning process of English as a Foreign Language

\section{APPENDIX D}

\section{Find someone who.}

is shy.

is cheerful.

is lazy.

is married.

is a call center.

has a car.

is not from Goiás. is generous.

is curious.

is courageous.

is single.

has a child/ kid.

has a motorcycle.

has 2 brothers. 